\title{
HVORDAN LESE ISLAMSKE ORNAMENTER I SKOLEN?
}

\section{Av Geir Winje}

\section{ABSTRACT}

This article presents various ways of symbolic reading of Islamic ornaments, derived from academic writings on the subject. They may be categorized as more or less minimalist or maximalist, depending on the degree of explicit meaning ascribed to geometric figures and stylized flowers. The different interpretations of ornamental art is then seen in connection with Religious Education in Norwegian school, and the article proposes among other things a reading in accordance with contemporary views on multimodality and composition. On a more fundamental level, the article discusses the use of religious primary sources in school, especially those representing minority religions. It argues in favour of a didactic model that differentiates between several dimensions in religious texts, spanning from concepts and values that are common to all mankind, to what is specific for the actual religion.

Geir Winje, f. 1955 Førstelektor, Høgskolen i Buskerud og Vestfold, Pb 235, 3603 Kongsberg, Geir.Winje@hbv.no

Denne artikkelen er et teoretisk og fagdidaktisk bidrag til RLE (religion, livssyn og etikk). Den belyser og forsøker å besvare følgende spørsmål: Hvordan skal elever i norsk skole kunne forstå islamsk kunst på en sakssvarende og faglig måte? Selv om emnet er smalt, har det prinsipiell betydning for religionsundervisningen, siden det dreier seg om hvordan læremidler, lærere og elever forholder seg til en minoritetsreligions primærkilder.

De fleste fagbøker om islamsk kunst handler om arkitektur og interiør i tilknytning til moskeer og andre bygninger med religiøs betydning, samt kalligrafi, ornamentikk og (mer omdiskutert) figurativ kunst med religiøs tematikk. I det følgende vies ornamentene størst oppmerksomhet, idet jeg gjør rede for ulike måter å lese eller fortolke dem på. Deretter ser jeg på disse lesemåtenes relevans for undervisningen $\mathrm{i}$ norsk skole, før jeg avslutningsvis mer prinsipielt tar for meg bruken av (islamsk kunst og andre) primærkilder i RLE.

\section{ISLAMSK ORNAMENTIKK - ULIKE LE- SEMÅTER}

Det islamske bildeforbudet er blant annet formulert i vers (ayat) 74 i sure 6 (Buskapen). Det forstås ofte av utenforstående som en kunstnerisk begrensning, men er i muslimsk estetikk et sakssvarende uttrykk for menneskets respons på Guds vesen og vilje, slik de kommer til uttrykk i Koranen. Fordi Gud har åpenbart sitt vesen og vilje i en tekst som først ble hørt av Muhammed og deretter nedskrevet, er muntlig og skriftlig gjengivelse av denne teksten de viktigste kunstformene. Korantekstene skal fremstilles tydelig og vakkert; muntlig av imamer og skriftlig av kalligrafer. ${ }^{1}$ Tekstene utsmykkes i resitasjon med ekstra toner og i skrift med geometriske ornamenter eller arabesker (planteornamenter). Enkelt sagt er den ornamentale kunstens oppgave å forskjønne Guds ord - enten det formidles muntlig eller skriftlig.

Islamsk kunst reflekterer matematikkens

1 Imam - fra arabisk: forbilde, leder - brukes i sunni-islam om den som leder bønnen i moskeen. 
utvikling i tiden fra de første kalifene til 1200tallet (Blair og Bloom 1997, Faruqi og Faruqi 1984, Hattstein og Delius 2000, Hillenbrand 1999). De eldste bevarte ornamentene er gjerne basert på trekantmønstre og stiliserte vinranker, men kompleksiteten økte etter hvert: fire-, seks-, åtte-, ti- og tolvkanter i ulike utforminger, samt oddetallsbaserte figurer, sirkel- og spiralformer. Gjennom hele perioden var symmetri et viktig virkemiddel, både speilsymmetri, rotasjonssymmetri og parallellforskyvning. Den geometriske kunstens utvikling henger også sammen med byggeskikk og materialvalg. Mens de eldste ornamentene ble hogd i stein eller tegnet på pergament, ble det etter hvert tatt i bruk keramiske fliser, både ensfargede og med påmalte mønstre, samt stukkatur, papir, pensler og penner.
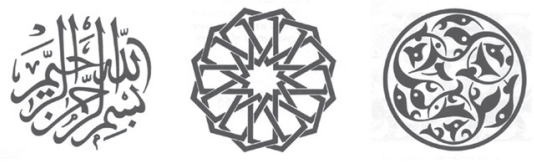

Det skjelnes gjerne mellom tre hovedtyper religiøs utsmykning: kalligrafi, rene geometriske figurer og arabesker. ${ }^{2}$ (Mange eksempler på nettsider som www.shutterstock.com, www. canstockphoto.com og www.pinterest.com - søk på «Islamic Ornaments».) Grensene mellom dem kan være flytende, for eksempel kan bokstaver «geometriseres» i så stor grad at de nærmest er uleselige. Ofte samvirker de tre typene også: I mange klassiske vestlige moskeer er veggene utsmykket med keramiske fliser og geometriske mønstre nederst, og stukkatur med kalligrafi og arabesker øverst. I østlige og mange nyere moskeer dominerer arabesker og kalligrafi.

Når tekster inngår i den ornamentale utsmykningen i for eksempel en moské, kan meningsinnholdet kaste et visst lys over utsmykningspro- grammet. De kan oppfordre til bønn og til å holde seg til Gud, eller de kan rett og slett være navn som Allah, Muhammed, noen av Guds 99 navn eller navnene på de første kalifene. På digitaltmuseum.no er norske moskeer godt dokumentert. Her finner vi blant annet World Islamic Missions moské i Åkebergveien i Oslo, der alle disse tekstene inngår i quibla-veggen som viser retningen mot Mekka. De mest iøynefallende tekstene er sure 112 (Enhetsbekjennelsen), som tematiserer Gud, og sure 108 (Overfloden), som tematiserer Muhammed. ${ }^{3}$ På quibla-veggen står også utdrag av dikt om Profeten og paradiset, skrevet av den persiske sufi-poeten Schirazi. Rundt mihraben, nisjen i quibla-veggen, står lysverset: «Gud er himlenes og jordens lys. Hans lys kan lignes med en nisje hvor det er et bluss (...) $\gg$ (Lyset / sure 24, 35-36).

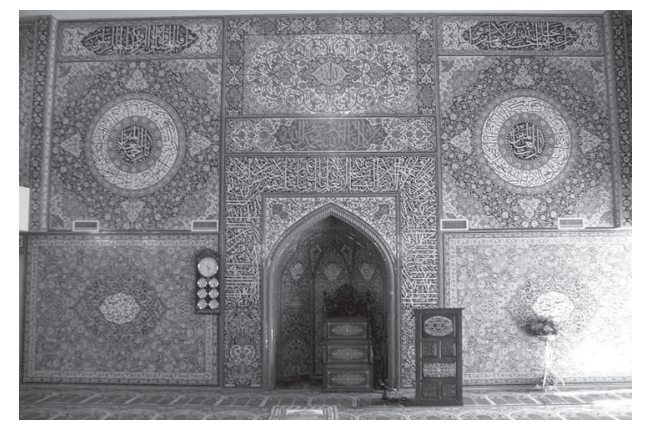

World Islamic Missions moské i Åkebergveien i Oslo. Foto: Anders Bettum. Oslo Museum

I andre moskeer kan mihraben smykkes med for eksempel vers 149 i sure 2 (Kua): «Hvor du enn kommer fra, så vend ditt ansikt mot den hellige moské!» eller vers 38 i sure 3 (Imrans hus), som forteller om Sakarias, som står ved helligdommen og ber Gud om å få en sønn (Johannes). Over inngangsdøren kan det stå tekster om døren som fører til fred og sikkerhet (f.eks. Al-Hidsjer eller Steinlandet / sure 15, 44-45, se også Nattreisen /sure 17, 80). Ved fontenene i store, historiske

2 Arabesk - fra fransk (jf. «arabisk») - brukes gjerne om planteornamenter, der linjer bukter seg og alle flater fylles ut. 3 Alle koransitater og -henvisninger gjelder Einar Bergs oversettelse (Berg, 2000). 
moskeer kan dekorative tekster påpeke vannets religiøse betydning (f.eks. Profetene / sure 21, 30), mens andre tekster trekker paralleller mellom taket og himmelen (f.eks. Skaperen / sure 35, 41). Tekstene etablerer på et vis moskeen som et mikrokosmos, og tydeliggjør hvordan elementer i den jordiske moskeen korresponderer med himmelske elementer.

Innenfor en slik tolkningstradisjon er det naturlig at også ikke-verbal utsmykning tillegges mening. Islamsk estetikk omfatter da også mange måter å tolke geometriske mønstre og arabesker på. Ingen av dem er imidlertid normative, det finnes ingen «fasit», så i det følgende presenteres forskjellige lesemåter. De er alle hentet fra faglitteratur på feltet, der de systematiseres på mange måter. I denne artikkelen er de ordnet $\mathrm{i}$ henhold til hvor detaljert ornamentene tolkes (Sinclair 2012, Renard 1996). Jeg gjør først rede for de mest minimalistiske lesemåtene, der verken geometriske figurer eller planteformer tillegges noen detaljert betydning. Deretter følger noen eksempler på en mellomposisjon, der ornamenter leses med vekt på formale trekk. Til sist presenteres maksimalistiske lesinger, der geometriske former tolkes mer eksplisitt.

Fagbøker som målbærer en mer eller mindre uttalt minimalistisk tolkning, hevder gjerne at hensikten med å utsmykke en moské eller Koran er å vise hvor verdifulle disse religiøse ressursene er. Som i andre kulturer fremheves og forskjønnes steder og gjenstander som er særlig betydningsfulle. En slik tolkning kan selvsagt kombineres med andre og mer spesifikke tolkninger. En av imamene i moskeen i Åkebergveien (se ovenfor) har gitt uttrykk for et lignende, tilbakeholdent syn på betydningen av ornamentikk (Winje 2012:215). Denne moskeen er rikt utsmykket med arabesker og kalligrafi, malt på kvadratiske fliser. Blå er hovedfargen, og selv om imamen representerte et minimalistisk syn, åpnet han for en assosiasjonsrekke fra fargen blå, via himmelen, til Gud. Han sa også at blomster og blader kunne forstås som uttrykk for liv, altså Guds skaperverk eller naturen. Imamen viste hvordan ornamenter kan forstås som meningsbærende uten å tolkes detaljert.

I en lignende tolkning representerer arabeskene orden fordi planteformene er basert på strenge geometriske grunnmønstre preget av symmetri, og liv fordi de samtidig virker frodige og levende (se f.eks. Clévenot og Degeorge 2000, Islam through Art og Murata og Chittick 1996). Når stengler slynger seg langs usynlige linjer og stiliserte blomster, blader og frukter fyller alle flater uten å bryte ut av innrammingen, kan det leses som et uttrykk for at alt som lever følger en lovmessighet som kan forstås rasjonelt og uttrykkes matematisk. Naturen er verken kaotisk eller tilfeldig, men rytmisk og forutsigbar. Islamske ornamenter kan i denne sammenhengen forstås som tekster som forteller eller viser at verden er skapt av Gud. Det er imidlertid ikke snakk om noen eksplisitt symbolikk der hver enkelt figur tillegges en presis betydning. Det er snarere snakk om en implisitt symbolikk, der formspråket gjør sterkt inntrykk på betrakteren, som fortolker det innenfor islam som kontekst. Kunsten kom først, mens lesemåtene er sekundære og antydende.

I to beslektede lesemåter forstås også symbolikken som implisitt: Den ene tilskriver kunsten en moralsk effekt (Ettinghausen 1976, Renard 1996): Når et mønster består av geometriske figurer som gjentas, oppleves kunsten som forutsigbar. Dermed faller betrakteren til ro, noe som forsterkes av symmetrien, som også har en harmonisk effekt. Når ornamentene formidler ro og harmoni, vil den som påvirkes av kunsten i sin tur påvirke andre, som også vil preges av ro og harmoni. Fordi harmoniske og trygge mennesker gjerne handler godt mot hverandre, gagner kunsten samfunnet. Den andre vektlegger kunstens teologiske effekt (Faruqi 1985): En som betrakter en utsmykket vegg på 
nært hold, ser først små, intrikate planteformer eller geometriske figurer. På litt større avstand ser en hvordan disse kombineres og gjentas på ulike måter. På enda større avstand kan en se hvordan planter eller figurer fyller et felt eller en modul, og deretter ser en at også modulene gjentas. Når et slikt mønster fyller en hel vegg, virker det som om det kan gjentas og utvides i det uendelige, og at veggen bare viser et lite utsnitt av en altomfattende struktur. Slik viser den til Guds skaperverk, som også er uendelig stort. Både ornamentene og skaperverket er preget av orden og gjentakelse, begge gjør et overveldende inntrykk, og begge sier noe om skaperen bak verket. Som en naturlig respons vil betrakteren til sist utbryte: Allahu akbar (Gud er større).

Her kan også nevnes at det noen ganger poengteres at islamske ornamenter mangler et markert sentrum (Ali 1999, Faruqi og Faruqi 1984, Faruqi 1985). Geometriske bånd- og tapetmønstre består av mange figurer, og hver figur har sitt eget sentrum. I tillegg dannes nye former med nye sentra der figurene overlapper hverandre. Når betrakteren flytter blikket, dukker derfor nye sentralpunkter stadig opp. Dette kan forstås som et estetisk motstykke til for eksempel hinduiske meditasjonsdiagrammer (yantraer), der sentrum (bindu - fra sanskrit: frø, sæd) kan representere menneskets guddommelige sjel (atman). Det står også i motsetning til kristen figurativ kunst, der Gud ofte avbildes som mennesket Jesus sentralt i bildet. Islamsk kunst korresponderer ikke med et menneskesyn som åpner for identifikasjon mellom menneske og Gud, men leses i samsvar med et syn på mennesket som fullt og helt en skapning. Denne påstanden må imidlertid modereres noe, siden quibla-veggen jo er symmetrisk, med mihraben som akse og naturlig blikkpunkt. Om nisjen tolkes som porten til paradiset, markerer derimot også den avstand mellom Gud og menneske. Denne vektleggingen av avstand mellom Skaper og skapning må balanseres mot en vektlegging av nærheten mellom Gud og menneske, jamfør vers 16 sure 50 (Qaf): «Vi er ham nærmere enn halspulsåren.»

Til sist skal nevnes at enkelte fagbøker også gjennomfører maksimalistiske lesinger og tolker geometriske figurer mer eksplisitt. Her forstås et geometrisk mønster som en kodet tekst der hver figur tilsvarer et tall, som igjen viser til en bokstav (Critchow 1976, Renard 1996 - se også Clévenot og Degeorge 2000, Moore 1977). To sekskanter eller heksagrammer kan for eksempel vise til to 6-tall og leses som «Allah» fordi $\mathrm{L}$ er den sjette bokstaven i alfabetet (Schimmel 1984). Numerologiske lesinger har vært særlig utbredt i visse historiske perioder, også innenfor andre religioner (f.eks. kabbalistisk jødedom). Slike spekulative lesemåter faller mest naturlig i miljøer med en esoterisk religionsforståelse, der hemmelig kunnskap formidles gjennom innvielser.

I motsetning til de minimalistiske lesemåtene (se ovenfor) er de maksimalistiske tilnærmingene kontroversielle. Skepsisen mot numerologiske og allegoriske lesinger av tall og figurer kan henge sammen med at de på et vis undergraver bildeforbudet. Dersom for eksempel 5 etableres som menneskets tall og 6 eller 7 som Guds tall, vil visse geometriske former få en fast betydning og i praksis fungere som en mer eller mindre abstrakt eller symbolsk form for figurasjon. En annen grunn til skepsis er at skjulte budskap og hemmelige betydninger gjør religionen eksklusiv og utilgjengelig for den vanlige mann og kvinne, stikk i strid med Koranens budskap.

Oppsummerende leses islamsk kunst verken som humanistisk eller naturalistisk, selv om den kan si noe om både mennesket og naturen. I stedet leses den i hovedsak symbolsk (Faruqi 1985). Lesemåtene det er gjort rede for, kan videre plasseres i tre til dels overlappende kategorier: Den første kategorien omfatter de mest minimalistiske 
lesemåtene, og den siste omfatter de mest maksimalistiske. I en mellomkategori finner vi lesemåter som skiller seg ut fordi tall og figurer ikke tolkes, verken detaljert eller mer antydende. Symbolikken karakteriseres her som implisitt, og lesemåtene vektlegger hvordan formale trekk som symmetri og repetisjon påvirker dem som betrakter ornamentene, og hvilke etiske, teologiske og antropologiske effekter det får.

\section{ULIKE LESEMÅTER I}

\section{UNDERVISNINGEN}

Norske elever lærer i hovedsak å lese figurativ kunst med vekt på ikonografi. Det skjer både i uformelle og formelle sammenhenger, ikke minst i fag som norsk og kunst og håndverk, der de særlig møter vestlig kunst. Samtidig skal elevene i RLE arbeide med religiøs kunst fra mange kulturer, noe som fordrer alternative tilnærmingsmåter. Kompetansemålene i Kunnskapsløftet er imidlertid upresise, og formuleringene er de samme uansett hvilken religion det gjelder. Elevene skal etter 4. årstrinn kunne «gjenkjenne kunst og gjøre bruk av estetiske uttrykk knyttet til» den enkelte religion (KD 2006). Etter 7. årstrinn skal de kunne «presentere ulike uttrykk fra kunst og musikk» og etter 10. årstrinn skal de kunne «beskrive og reflektere over særtrekk ved kunst, arkitektur og musikk». Samtidig sier formålsbestemmelsen for RLE at «alle religioner og livssyn skal behandles på en faglig og sakssvarende måte ut fra sitt særpreg og mangfold» (ibid.). Elevene må derfor gjøres kjent med en islamsk forståelse av islamsk kunst, uten å ta utgangspunkt i en negativ definisjon av kunsten som ikke-figurativ.

Lærebøkene i RLE legger opp til en forholdsvis enkel lesing av islamsk kunst. I Horisonter 8 heter det for eksempel: «Kunsten skal være til ære for Gud, og bildeforbudet har ført til en oppfinnsom bruk av ornamenter (gjentatte, vakre mønstre) og kalligrafi (vakker skrift)» (Holth og Deschington 2006:96).
Etter denne forståelsen er islamske ornamenter erstatninger for bilder. Under samme himmel 1 nærmer seg islamsk kunst på en mer sakssvarende måte: «Gjennom blant annet kalligrafi og ornamentikk viser muslimske kunstnere Guds enhet og skaperverkets orden og rike variasjon. Islamsk kunst er symbolsk og abstrakt, for den er ikke en direkte kopi av det vi kan se i naturen. Ornamentikk betyr utsmykningskunst» (Wiik og Waale 2006:112).

Alle lesemåtene som er trukket fram i denne artikkelen, tillegger ornamentene en eller annen form for religiøs betydning eller effekt. Når elevene gjøres kjent med dem, blir det vanskeligere å tolke denne kunsten som en oppfinnsom konsekvens av bildeforbudet. Den mest minimalistiske lesemåten (ovenfor) bør uten problemer kunne introduseres for de yngste elevene. Her forstås ornamentene som markører som fremhever steder og gjenstander med en særskilt religiøs verdi eller betydning, og det er konteksten som gjør kunsten «religiøs». Siden det er vanlig å utsmykke betydningsfulle steder og gjenstander, er en slik lesemåte både gjenkjennelig og enkel å forstå, uansett alder eller kulturell bakgrunn. Lesingen som assosierer fargen blå med himmelen (og Gud) og lar arabeskenes planteformer representere det livet Gud har skapt, bør også kunne gjennomføres på 1.-4. trinn. Fordi yngre elever kan tro at en slik lesing er «korrekt », bør de få kjennskap til flere lesemåter samtidig, uten at de harmoniseres. Elever på 5.-7. trinn bør også kunne gjennomføre den mer krevende lesingen der geometriske figurer representerer orden og lovmessighet som forutsetninger for liv og variasjon (planteformene). Ingen av disse lesemåtene er særlig kompliserte eller kontroversielle, og de kan godt kombineres (men helst etter at elevene har møtt dem som selvstendige alternativer).

En mulig tverrfaglig elevaktivitet i forlengelsen av undervisning om sistnevnte lesemåte, kan 
være å konstruere et skjelett av geometriske figurer som gjentas slik at de danner et båndeller tapetmønster. Deretter kan elevene føye til stiliserte planter som slynger seg langs alle linjer og fyller alle flater. Til sist fjernes skjelettet, slik at kun planteformene står igjen. Det er imidlertid ulike syn på om, og eventuelt hvordan, religiøse primærtekster bør trekkes inn i undervisningen på denne måten, noe som tas opp senere i artikkelen.

På mellomtrinnet skal elevene ifølge læreplanen også «samtale om islam, islamsk livstolkning og etikk» (KD 2006). Om det ikke blir for krevende eller fremmedartet, kan de i den forbindelse få høre om lesemåten som vektlegger kunstens moralske effekt (ovenfor). De skal også lære mer generelt om «filosofi, religion og livssyn som grunnlag for etisk tenkning» (ibid.), og det kan gi mening å utveksle tanker og synspunkter på både kunst og etikk: Hva liker elevene og hva liker de ikke? Hvordan opplever de gjentagelse og symmetri? Kan slik kunst skape ro og harmoni, eller er den bare kjedelig fordi den ikke overrasker eller bruker figurasjon? Er det en sammenheng mellom indre harmoni og en vennlig holdning til andre mennesker? Det er i denne forbindelse interessant at $\mathrm{Vi}$ i verden 5 sier: $\ll$ I noen moskeer er veggene vakkert dekorert. Det er ikke lov å ha bilder av noe i moskeen. I stedet kan det være vakre mønstre og fin skrift. (...) I noen moskeer er veggene ensfargede. Noen mener det er lettere å konsentrere seg om Gud da» (Berg m.fl. 2006:56). Jeg har ikke kommet over noe lignende syn på ensfargede vegger i faglitteraturen.

På ungdomstrinnet skal elevene «forklare særpreget ved islam og islamsk tro som livstolkning $\mathrm{i}$ forhold til andre tradisjoner: likhetstrekk og grunnleggende forskjeller» (KD 2006). De kan eventuelt introduseres for lesemåtene som vektlegger sammenhenger mellom ornamentene og menneskets opplevelse av seg selv som skapt av en Gud som er uendelig mye større enn mennesket (ovenfor). Det kan imidlertid være problematisk å bruke dem i skolen, da de krever en grad av innlevelse som kan være uheldig. Det kan også være vanskelig å arbeide med antydende tolkninger av formale forhold fremfor mer eksplisitt symbolikk.

Elevene kan eventuelt arbeide med denne kunsten på måter som er mindre involverende og mer konkrete. De kan for eksempel gjennomføre en matematisk tilnærming og beskrive og konstruere geometriske mønstre og eventuelt arabesker (Melhus og Winje 2009, Winje 2014). Ifølge læreplanen i matematikk skal elevene på 2.-4. trinn arbeide med både speilsymmetri og parallellforskyvning (KD 2006). En så praktisk arbeidsform kan kombineres med samtaler om kunstens religiøse funksjon. I den forbindelse kan ett av flere mulige grep være å undersøke hva de dekorative tekstene som inngår $\mathrm{i}$ moskéutsmykningen, sier (se ovenfor). Selv om koransitatene er arabiske, finnes engelskspråklig informasjon om «Decorative Texts» $\mathrm{i}$ en del kjente moskeer på Internett (se også Winje 2002).

De mest maksimalistiske lesingene nevnt ovenfor egner seg neppe i RLE, da de er spekulative og lite representative for norske muslimer. Skal elevene likevel arbeide med kodeknekking i RLE, er det viktig å knytte an til flere religioner, slik at de ikke får inntrykk av at numerologiske lesemåter er typiske for islam. De må plasseres i sine respektive historiske kontekster.

En arbeidsmåte som kan egne seg på ungdomstrinnet, innebærer å nærme seg utsmykkede vegger, koraner, etc, som sammensatte tekster, og ornamentene som modaliteter i samspill med andre modaliteter. En slik tilnærming lar elevene ta i bruk flere kompetanser, jamfør læreplanen i norsk, som sier at elevene etter 10. årstrinn skal kunne «vurdere estetiske virkemidler i sammensatte tekster hentet fra informasjons- og under- 
holdningsmedier, reklame og kunst og reflektere over hvordan vi påvirkes av lyd, språk og bilder» (KD 2006). En slik oppmerksomhet på tekstenes påvirkningskraft er viktig i et fag som RLE, der elevene stadig møter forkynnende primærtekster.

Når en undersøker hvordan ulike modaliteter virker sammen, hører det med å se på komposisjon og andre formale forhold. Semiotikeren Gunther Kress og lingvisten Theo van Leeuwen (2006) har sett nærmere på blant annet innramming, symmetri, elementenes plassering langs vertikale og horisontale akser og i sentrum versus periferi. De er opptatt av hvordan slike komposisjonsgrep påvirker leseren eller formidler mening, og peker blant annet på to forhold: 1) Komposisjonen styrer leserens oppmerksomhet i en spesiell retning og forteller eller antyder hvor viktig informasjon er å finne. 2) Innramming av elementer gir inntrykk av svakere kontinuitet og sammenheng mellom elementene, mens manglende rammer tyder på kontinuitet og flyt.

Det første forholdet Kress og van Leeuwen trekker fram, faller sammen med den første lesemåten som ble presentert ovenfor. En quiblavegg kan for eksempel være komponert slik at oppmerksomheten ledes mot mihraben, og elevene vil i den forbindelse kunne stille spørsmål som: Hvorfor er mihraben så viktig? Hvorfor viser den retningen mot Mekka? Og hvorfor er Mekka så betydningsfull? Når undervisningen tar utgangspunkt i noe konkret og visuelt, vil erfaringsmessig flere elever ta del i en utforskende samtale (Grimmitt 2000). Da vil de også henge bedre med når samtalen dreies mot mer abstrakte forhold, i dette tilfellet tawhid. ${ }^{4}$ Eldre elever kan også studere interiør og utsmykning i moskeer, kirker og templer, lese dem som sammensatte tekster og sammenligne dem med tanke på hvordan og mot hva oppmerksomheten ledes.
Det andre forholdet kan ses i sammenheng med lesemåten som vektlegger hvordan geometriske figurer og planteornamenter utfolder seg innenfor innrammede felt i stedet for å flyte grenseløst ut over alt. Hvert felt fremstår som en selvstendig enhet, atskilt fra de andre feltene. De er ikke identiske, men de bakenforliggende geometriske prinsippene er likevel de samme. På samme måte har mennesker og andre skapninger noe grunnleggende felles, selv om de er ulike og atskilt fra hverandre.

Når elevene får kjennskap til flere måter å tolke kunsten på, utnyttes sannsynligvis læringspotensialet best, og det er større sjanse for at den virker like viktig og meningsfull som andre religioners kunst. Kjennskap til flere lesemåter forhindrer også at én lesemåte forstås som autorisert eller «riktig». Det er naturlig å arbeide tverrfaglig med geometrisk kunst, og i tillegg til RLE, matematikk og kunst og håndverk peker norskfaget seg ut når elevene skal lese ornamenter som sammensatte tekster.

\section{MER PRINSIPIELT OM KUNST OG AN- DRE PRIMÆRKILDER I RLE}

Undervisningen om religioner skal ifølge formålsbestemmelsen for RLE «være objektiv, kritisk og pluralistisk» (KD 2006). Det er derfor problematisk at kunst, hellige skrifter og andre primærkilder i stor grad er forkynnende, og at besøk i moskeer, kirker og templer kan oppleves som altfor involverende. Det er nærliggende å unngå slike kilder eller droppe undervisning som på andre måter «kan oppleve[s] som utøvelse av annen religion eller tilslutning til annet livssyn» (ibid. - se også $\$ 2-3a i Opplæringsloven). Utfordringen kan bli enda større dersom religionenes fortellinger eller andre kilder trekkes inn i undervisningen om andre emner enn de religionene kildene er hentet fra. Er det for eksempel forsvarlig å bruke fortellingen om 
den barmhjertige samaritan eller Buddhas møte med morderen Angulimala i undervisningen om allmenn etikk? Eller bør slike fortellinger kun trekkes inn når undervisningen handler om henholdsvis kristen og buddhistisk etikk?

I denne artikkelen har jeg foreslått både formingsaktiviteter og etikkundervisning inspirert av islamsk kunst. Artikkelen støtter altså et didaktisk prinsipp som hevder at elevene kan lære $a v$ religioner samtidig som de lærer om religioner (Meier 2009). En beslektet tankegang ligger bak en didaktisk modell som skjelner mellom ulike dimensjoner i religionenes fortellinger (Breidlid og Nicolaisen 2011). Den er utviklet av religionspedagogene Halldis Breidlid og Tove Nicolaisen, og må ikke forveksles med Ninian Smarts dimensjonsmodell, som opererer med sju sider eller dimensjoner ved religioner. Breidlid og Nicolaisens modell gjelder tematikken i religionenes fortellinger, og omfatter tre dimensjoner eller nivåer: en allmenn eller allmennmenneskelig dimensjon (f.eks. verdier som de aller fleste kan slutte seg til), en religiøs eller fellesreligiøs dimensjon (f.eks. troen på en gud) og en religionsspesifikk dimensjon (trosforestillinger og verdier som er særegne for den aktuelle religionen). Enkelt sagt kan elevene i en og samme tekst finne tanker og verdier på ulike nivåer i spennet mellom det allmenne og det religionsspesifikke. Dersom en ikke-muslimsk elev opplever at fortellingen om Muhammeds første åpenbaring handler om angst, tvil og tillit på et generelt eller allmennmenneskelig nivå, forholder hun seg til den allmenne dimensjon. Samtidig kan hun oppleve fortellingens religionsspesifikke dimensjon som irrelevant, mens det for en annen elev kan være omvendt.

Både tanken om en allmenn dimensjon og tanken om å lære $a v$ religionene har imidlertid møtt kritikk (se f.eks. Kvalvaag 2002). Da Breidlid og Nicolaisens modell ble lansert, ble det påpekt hvor uheldig det kunne være for elevene å måtte forholde seg til en oppkonstruert «allmenn dimensjon» preget av moderne humanistiske tanker og verdier. Religionenes tekster burde i stedet leses som det de faktisk er, nemlig uttrykk for religionsspesifikke, førmoderne forestillinger og verdier. De siste årene har modellen nok en gang fått kritikk, denne gangen fordi vektleggingen av en allmenn dimensjon i religionenes fortellinger innebærer «en aktiv fortolkning og bruk av fortellingen, og den relateres til den enkelte elevs liv på en måte som kan oppfattes som tilslutning til en annen religion eller livssyn» (Andreassen 2012:114).

Denne kritikken er berettiget. En fortolkningsmodell som tillegger religionenes fortellinger en allmenn dimensjon, kan fungere tilslørende og underkommunisere hvor forskjellige religionene faktisk er. Den kan få elevene til å åpne seg for religiøse budskap som ikke blir identifisert som religiøse. Jeg vil likevel hevde at dimensjonsmodellen egner seg i RLE, så sant den brukes med klokskap, varsomhet og respekt for religionsspesifikke forskjeller. Den tilbyr et vokabular og noen kategorier som kan hjelpe elevene med å sortere inntrykk og tanker og se at religionene, og dermed mennesker med tilhørighet i religionene, har noe felles, selv om de ikke har alt felles. I et integreringsperspektiv er det viktig å synliggjøre både likheter og forskjeller mennesker og kulturer imellom. Uten å synliggjøre ulikhetene, kan en ikke forholde seg til dem, og uten bevissthet om likhetene, er det vanskelig å etablere fellesskap. Et ensidig fokus på kultur- eller religionsspesifikke forskjeller kan virke segregerende, mens en unyansert vektlegging av den allmenne dimensjon kan virke assimilerende.

Når skolen arrangerer møter mellom elever og primærkilder, bør de selvsagt foregå på en strengt faglig måte og med et særlig fokus på tekstenes opprinnelige kontekst. Likevel vil enkelte elever reagere mer spontant og personlig 
enn andre - uansett hvilken religionshistorisk bakgrunn kildene måtte ha. Disse elevene kan oppleve at tanker, personer eller handlinger som de møter i tekstene, bekrefter eller kolliderer med egne synspunkter og erfaringer, selv om andre elever kan oppleve dem som uinteressante. Dimensjonsmodellen kan hjelpe elevene med å skjelne mellom ulike sider ved tekstenes budskap og dermed nyansere sine reaksjoner på både tekstene og religionene de representerer.

I norsk kontekst identifiseres ofte det allmenne med det vestlige. Opplæringsloven bruker da også uttrykket «kristne og humanistiske verdier» om skolens verdigrunnlag, og lærere og lærebøker trekker særlig fram humanistiske, kristne og til dels jødiske filosofer og etikere når de tar for seg allmenn etikk. En lignende tendens innebærer at «kunst» forstås som vestlig og at islamsk kunst er «annerledes». Denne annerledesheten forsterkes av bildeforbudet, men den bilderike kunsten i østlige religioner plasseres også utenfor «det allmenne». Denne diskriminerende tendensen kan motvirkes på flere måter:

Én måte kan som nevnt være å fokusere på både det allmenne og det religionsspesifikke i arbeidet med primærkilder, uansett hvilke religioner eller livssyn de representerer. Om en vektlegger den allmenne dimensjon $\mathrm{i}$ arbeidet med et bilde av Krishna som danser på hodet til slangedemonen Kaliya, kan en tematisere egenskaper og verdier som eventyrlyst, vennlighet, mot og tilgivelse. Arbeider elevene med et bilde av Jesus som bærer på et lam, kan en vektlegge mulige fellesverdier som omsorg, individualitet og trofasthet. En kan samtidig få fram religionsspesifikke sider ved de samme bildene og gi elevene innblikk i hvor forskjellige religionene faktisk er, både når det gjelder tro og etikk. Om den religionsspesifikke dimensjonen underkommuniseres, fratas religionene sitt særpreg, og dagens kulturelle mangfold tilsløres i stedet for å tydeliggjøres.
En annen måte å motarbeide at vestlige ideer og verdier er alene om å få status som allmenne, er å bruke ikke-vestlige tekster som kilder eller illustrasjoner, for eksempel i arbeidet med allmenn etikk. Verken et bilde av Krishna eller en fortelling om Buddha må nødvendigvis leses kun religionsspesifikt. De kan begge leses med en viss oppmerksomhet på den allmenne dimensjon. Og når en islamsk lesemåte ser en sammenheng mellom ornamenter preget av symmetri og rytme og mennesker preget av harmoni (ovenfor), kan også slik kunst trekkes inn i undervisningen om allmenn etikk - ikke som en dominerende kilde, men for å unngå at andre kilder blir dominerende.

\section{LITTERAT UR}

Ali, Wijdan. 1999. The Arab Contribution to Islamic Art. From the Seventh to the Fourteenth Centuries. Gainesville: University Press of Florida.

Andreassen, Bengt-Ove. 2012. Religions-didaktikk. En innføring. Oslo: Universitets-forlaget.

Berg, Einar (overs.). 2000. Koranen. Oslo: De norske bokklubbene.

Berg, Mari Ann m.fl. 2006. Vi i verden 5. Oslo: Cappelen.

Blair, Sheila S. og Bloom, Jonathan M. 1997. Islamic Arts. London: Phaidon.

Breidlid, Halldis og Nicolaisen, Tove. 2. utg. 2011. I begynnelsen var fortellingen. Oslo: Universitetsforlaget.

Clévenot, Dominique og Degeorge, Gérard. 2000. Ornament and Decoration in Islamic Architecture. London: Thames \& Hudson.

Critchlow, Keith. 1976. Islamic Patterns. London: Thames \& Hudson.

Ettinghausen, Richard. 1976. «Al-Ghazzali on Beauty» i Ackerman, James S. (red.). The Garland Library of the History of Art. Volume 13: Islamic Art and Architecture. New York/ London: Garland. 
Faruqi, Isma'il R. al og Faruqi, Lois Lamya al. 1984. The Cultural Atlas of Islam. New York: Macmillian Publishing Company.

Faruqi, Lois Ibsen al. 1985. «An Islamic Perspective on Symbolism in the Arts. New Thoughts on Figural Representation» i Apostolos-Cappadona, Diane (red.). Art, Creativity and the Sacred. New York: Crossroads.

Grimmitt, Michael. 2000. Pedagogies of Religious Education. Great Wakering: McCrimmons.

Hattstein, Markus og Delius, Peter (red.). 2000. Islam: Art and Architecture. Köln: Könemann.

Hillenbrand, Robert. 1999. Islamic Art and Architecture. London: Thames \& Hudson.

Islam through Art. u.å. Upton: The Goodwill Art Service.

Kress, Gunther og van Leeuwen, Theo. 2. utg. 2006. Reading Images. The Grammar of Visual Design. London: Routledge.

Kunnskapsdepartemnetet (KD). 2006. Lereplanverket for Kunnskapsløftet (LK06). Oslo: Kunnskapsdepartementet. (Lastet ned fra www.udir.no/Lareplaner/ Kunnskapsloftet/ 01.04.14.)

Kvalvaag, Robert. 2002. «Er det allmennmenneskelig å være religiøs?» i Religion og livssyn $\mathrm{nr} 2$.

Meier, Ralph. 2009. «Lære om og lære av religion. Om religionsundervisning i England sammenlignet med Norge» i Løvlie, Birger m.fl (red.), Danning, identitet og dialog. Festskrift til Jan Ove Ulstein og Per Magne Aadnanes. Trondheim: Tapir.
Melhus, Kersti og Winje, Geir. 2009. «Å regne i RLE» i Fauskanger, Janne m.fl. (red.), Å regne $i$ alle fag. Oslo: Universitetsforlaget.

Moore, Albert. 1977. Iconography of Religions. An Introduction. London: SCM Press.

Murata, Sachiko og Chittick, William C. 1996. The Vision of Islam. London/New York: I. B. Tauris.

Renard, John. 1996. Seven Doors of Islam. Spirituality and the Religious Life of Muslims. Berkeley/Los Angeles/London: University of California Press.

Schimmel, Annemarie. 1984. Calligraphy and Islamic Culture. New York/London: New York University Press.

Sinclair, Susan (red.). 2012. Bibliography of Art and Architecture in the Islamic World. Volume 1, Art. Leiden/Boston: Brill.

Wiik, Pål og Waale, Ragnhild Bakke. 2006. Under samme himmel 1. Oslo: Cappelen.

Winje, Geir. 2002. Moskeen. Oslo: Aschehoug.

Winje, Geir. 2. utg. 2011. Guddommelig skjønnhet. Kunst i religionene. Oslo: Universitetsforlaget.

Winje, Geir. 2014. «Grunnleggende ferdigheter i RLE» i Skovholt, Karianne, Innføring $i$ grunnleggende ferdigheter. Praktisk arbeid på fagenes premisser. Oslo: Cappelen Damm. 